doi $10.15826 /$ recon.2019.5.3.012

\title{
Implementation mechanisms of strategies of socio-economic territorial development: methodological approach
}

\section{A. Antipin \\ Ural State Economic University, Ekaterinburg, Russia; e-mail: aia87@mail.ru}

\section{ABSTRACT}

The article analyzes strategic planning and management in Russia. At present the latter can be characterized as lacking a unified methodological approach to devising strategies of territorial socio-economic development, including mechanisms of strategy implementation. Conceptually this study relies on the theory of strategic management, regional and spatial economics, on dialectical, cause-and-effect, and other methods. An overview of approaches to strategies in Russian and international studies is provided. The article also describes the long-term challenges faced by Russian economy at the turn of the millennium and the goals of national development. The main stages of strategic planning are outlined as well as the current state of strategic planning and management. It is shown that strategic planning and management are crucial for the development of territories on all levels (municipal, regional and national). A special emphasis is placed on the case of Ekaterinburg and other large Russian cities and the possibilities of using their experience in other territories. Some recommendations are formulated as to the ways and means of creating mechanisms for implementation of socio-development strategies. The resulting algorithm is shown to be optimal for building strategy implementation mechanisms, which makes this study both theoretically and practically relevant.

\section{KEYWORDS}

territory, strategic planning, strategic management, strategy of socioeconomic development, strategy implementation mechanism ACKNOWLEDGEMENTS The research was funded by Academician Nikolai Fedorenko International Scientific Foundation of Economic Research, project No. 2018-122.

\section{FOR CITATION}

Antipin I. A. (2019) Implementation mechanisms of strategies of socio-economic territorial development: methodological approach. R-economy, 5(3), 115-122. doi: $10.15826 /$ recon.2019.5.3.012

\section{Исследование механизмов реализации стратегии социально-экономического развития территории: методический подход}

\section{И. А. Антипин}

Уральский государственный экономический университет, Екатеринбург, Россия; e-mail: aia87@таil.ru

\section{АННОТАЦИЯ}

Статья посвящена исследованию процессов стратегического планирования и управления в Российской Федерации, одной из особенностей которых является отсутствие единых методических подходов к формированию стратегий социально-экономического развития территорий, в том числе к определению механизмов их реализации. Методологическая база исследования основывается на теоретических положениях стратегического менеджмента, региональной и пространственной экономики. Подходы российских и зарубежных ученых к стратегиям, этапы эволюции стратегического планирования в России, а также особенности разработки (актуализации) стратегий социально экономического развития, в том числе механизмов их реализации, территорий различных иерархических уровней раскрыты путем использования совокупности методов: диалектического, причинно-следственного и т.д. Представлены долговременные системные вызовы для российской экономики, сформировавшиеся в начале XXI в., а также стратегические цели современного развития Российской Федерации. Представлены основные характеристики этапов стратегического планирования, а также современное состояние процессов стратегического планирования и стратегического управления в Российской Федерации. Акцентировано внимание на необходимости применения механизмов стратегического планирования и стратегического управления развитием территорий. Проанализированы особенности механизма реализации стратегий Екатеринбурга и иных крупнейших городов Российской Федерации, а также возможности их применимости (тиражируемости) в стратегическом управлении другими регионами Российской Федерации. Сформулированы рекомендации по формированию механизма реализации стратегии социально-экономического развития. Теоретическая и практическая значимость исследования заключается в том, что оптимальное выстраивание алгоритма механизма реализации стратегии обуславливают прогрессивность социально-экономического развития территорий различных иерархических уровней. (C) I. A. Antipin, 2019

\section{КЛЮЧЕВЫЕ СЛОВА}

территория, стратегическое планирование, стратегическое управление, стратегия социально-экономического развития, механизм реализации стратегии

\section{БЛАГОДАРНОСТИ}

Работа выполнена при финансовой поддержке Международного научного фонда экономических исследований академика Н.П. Федоренко. Проект № 2018-122.

\section{ДЛЯ ЦИТИРОВАНИЯ}

Antipin I. A. (2019) Implementation mechanisms of strategies of socio-economic territorial development: methodological approach. R-economy, 5(3), 115-122. doi: 10.15826/recon.2019.5.3.012 


\section{Introduction}

At the turn of the millennium, Russian economy faced the following long-term systemic challenges, stemming from international trends but also from the country's internal issues: "firstly, increased global competition, covering not only the traditional commodity markets of capital, technology and labour, but also the national control system, support for innovation, human potential development; secondly, the expected new wave of technological changes, reinforcing the role of innovation in economic and social development and reducing the impact of many traditional growth factors; thirdly, the increasing importance of the role of human capital as a key factor in economic development; and, finally, the exhaustion of the potential of the raw materials export model of economic development based on forced export of fuel and raw materials, production of goods for domestic consumption due to the pre-loading of capacities in the conditions of low exchange rate, low cost factors of production - labour, fuel and electricity"'.

To achieve a breakthrough in the technological and socio-economic development of Russia, to improve the living standards and conditions and create for Russian people an environment and opportunities to fulfil their potential, the Russian government approved the goals of national development for the period until $2024^{2}$. These goals include the following: "enhance technological development of the Russian Federation, increase the number of organizations that implement technological innovation; stimulate digitalization in economy and the public sphere; ensure that the rates of economic growth should exceed the world level while maintaining macro-economic stability and that Russia should become one of the top five largest world economies; support high-productivity export-oriented businesses in the basic sectors of economy, primarily, in manufacturing and agriculture, based on modern technology and staffed with highly qualified employees"3.

${ }^{1}$ For more on the Concept of Long-Term Socio-Economic Development of the Russian Federation until 2020, see: Resolution of the Government of the Russian Federation of 17.11.2008. No. 1662-p.

${ }^{2}$ For more on the national and strategic goals of development of the Russian Federation until 2024, see: Decree of the President of the Russian Federation of 07.05.2018 No. 204.

${ }^{3}$ For more on the national and strategic goals of development of the Russian Federation until 2024, see: Decree of the President of the Russian Federation of 07.05.2018 No. 204.
To address the above-described systemic challenges and achieve the desired breakthrough, it is necessary to have a clear vision of what needs to be done, which is impossible without comprehensive strategic planning and management. The latter includes adequate mechanisms of strategy implementation, a plan of action, sufficient resources and so on, depending on specific needs of territories on different hierarchical levels (national, regional and municipal).

This article aims to investigate the mechanisms of implementation of strategies of socio-economic territorial development and to offer recommendations for devising such mechanisms within the general strategy framework.

\section{Methodology}

This study is based on the analysis of the key documents used in strategic planning such as officially approved strategies of cities, regions and so on and similar documents. The analysis relies on a set of methods (dialectical, cause-and-effect, etc.) to investigate specific stages in the cycle of strategic planning and management.

We also consider external and internal environment, methods of strategic analysis, missions, aims, objective and problem tree, strategy structure, priorities, key areas, programs, projects, methods of implementation, system of monitoring and management.

In this article we are dealing only with the implementation mechanisms for strategies adopted by territories of different hierarchical levels.

There is a vast body of research literature on strategic planning and management. In Russian and international practice of strategic planning, a strategic plan (or a strategy) is usually a document describing priority (strategically important) areas of development for a certain territory which different local community groups have chosen and agreed upon [1]. Undoubtedly, it is crucial to take into consideration opinions and interests of different stakeholders when setting the priorities of a public policy and devising strategic planning documents.

There is no universally accepted single definition of a strategy. A significant contribution to the research in this field was made by G. B. Kleiner [3], M. Porter [4], I. Ansoff [5; 6], A. A. Thompson, A. J. Strickland [7], H. Mintzberg, J. Quinn, S. Ghoshal [8] and others.

In our opinion, the following definition is the most adequate: strategy is a complex of clearly de- 
fined goals; policy, that is, the art of implementing the key goals and coordinated actions (ways of implementation) necessary to reach the desired goals [9].

The main stages in the evolution of strategic planning in Russia are described in Table 1.

Table 1

Main stages in the evolution of strategic planning in Russia [10]

\begin{tabular}{|l|l|l|}
\hline \multicolumn{1}{|c|}{ Period } & $\begin{array}{l}\text { Characteristics on } \\
\text { the territorial (state) } \\
\text { level }\end{array}$ & $\begin{array}{l}\text { Strategic planning } \\
\text { instruments }\end{array}$ \\
\hline $\begin{array}{l}\text { 1. Pre-rev- } \\
\text { olutionary } \\
\text { (1860-1920s) }\end{array}$ & $\begin{array}{l}\text { Planning of eco- } \\
\text { nomic development, } \\
\text { budget planning, for- } \\
\text { eign economic plans } \\
\text { as a part of strategic } \\
\text { planning concerning } \\
\text { military and political } \\
\text { alliances }\end{array}$ & $\begin{array}{l}\text { Basic statistical } \\
\text { analysis, non-for- } \\
\text { malized expert } \\
\text { assessment }\end{array}$ \\
\hline $\begin{array}{l}\text { 2. Soviet } \\
\text { (1920s-1990s) }\end{array}$ & $\begin{array}{l}\text { Directive planning of } \\
\text { all aspects of national } \\
\text { economy, high degree } \\
\text { of centralization }\end{array}$ & $\begin{array}{l}\text { Five-year plans, } \\
\text { technical, eco- } \\
\text { nomic and } \\
\text { project-based ap- } \\
\text { proach, schemes of } \\
\text { territorial develop- } \\
\text { ment and distri- } \\
\text { bution of labour } \\
\text { force, extrapolation }\end{array}$ \\
\hline $\begin{array}{l}\text { 3. Contempo- } \\
\text { rary (mid- } \\
\text { 1990s-pres- } \\
\text { ent) }\end{array}$ & $\begin{array}{l}\text { National, regional } \\
\text { and local strategic } \\
\text { documents, compre- } \\
\text { hensive strategies of } \\
\text { territorial develop- } \\
\text { ment (regional and } \\
\text { municipal levels), } \\
\text { development of } \\
\text { industries, strategies } \\
\text { of national socio-eco- } \\
\text { nomic development, } \\
\text { creation of the } \\
\text { strategic planning } \\
\text { infrastructure }\end{array}$ & $\begin{array}{l}\text { Strategic anal- } \\
\text { ysis, statistical } \\
\text { analysis, SWOT, } \\
\text { PEST-analysis, } \\
\text { systems approach, } \\
\text { scenario planning } \\
\text { and forecasting, } \\
\text { expert assessment, } \\
\text { foresight, strategic } \\
\text { control, strategic } \\
\text { assessment of } \\
\text { strategic planning } \\
\text { documents and } \\
\text { so on }\end{array}$ \\
\hline
\end{tabular}

If we analyze modern approaches to strategic planning and management, it becomes evident that the majority of such studies treat strategic planning as an effective mechanism of regional planning. Moreover, it is shown that any region's internal resources and potential depend to a certain extent on the external environment.

\section{Strategic planning and strategic management in Russia: contemporary stage}

At the modern stage of development in Russia, strategic planning and management start to be seen as crucial on all levels of the territorial hierarchy: national, regional, and municipal.
One of the key features of strategic planning in Russia is that when strategy documents were first designed, there was no legislation to regulate this process. The first strategy document the Strategic Plan of St.Petersburg - appeared in 1997. Thus, million-plus and large Russian cities became pioneers of strategic planning [11]. Nevertheless, even 22 years later, not all Russian regions and municipalities have adopted and started implementing up-to-date strategies of development. The situation with million-plus Russian cities inspires more optimism: as of 1 January 2019, all million-plus Russian cities (except for Krasnoyarsk) have officially approved strategies of socio-economic development and have started implementing them.

Even though Russia has already accumulated considerable experience in strategizing, strategic planning and management, a number of problems still remain unsolved [12]: the lack of methodological guidelines necessary for designing and implementing strategy documents; gaps in the legislation on strategic planning; insufficient coordination of the processes of strategic territorial planning and management; the lack of clear understanding of what stakeholder groups should participate in strategic planning and how this process should be organized; the lack of generally accepted mechanisms of strategy implementation; and so on.

It is necessary to improve strategic planning and management methods, in particular those of constructing (designing and updating) strategies of socio-economic development, including implementation mechanisms. It should be noted that at the current stage, Russian scholars take a special interest in the questions of forecasting [13]; strategic planning and strategic management $[14 ; 15]$, including the methodological support of this process $[16 ; 17]$; coordination of processes of territorial planning and management [18]; and development of "smart cities" [19-21]; and innovative development $[22 ; 23]$.

\section{Mechanisms of implementation of strategies of socio-economic development of Russian territories}

For efficient strategic planning and management it is important to identify mechanisms of strategy implementation. This section, however, is not always included in the strategies of socio-economic development. In some cases, different types of implementation mechanisms are declared (eco- 
nomic, financial, legal, organizational, etc.) but not clearly defined - no instructions are provided as to what, when and how the participants of the process should do.

The main mechanisms of implementation of the Strategic Development Plan of Ekaterinburg, which was among the first in Russia to engage in strategic planning, included involvement of different stakeholder groups (business, public, academia, government and mass media) into strategic planning and implementation.

Project management was combined with program management.

Ekaterinburg's Strategic Development Plan consists of strategic projects. Each project, in its turn, comprises a set of measures aimed at tackling specific problems, which facilitates project management and strategy implementation control. For the same purpose, unified methodological approaches are applied to strategic planning.

Last but not least, the processes of strategic and territorial planning and management are coordinated.

From 2003 to 2018, one of the main parts of Ekaterinburg's Strategic Plan was "The General Plan of the City of Ekaterinburg - City for Life". After 2018, it was replaced by the Strategy of Spatial Development, which addresses a number of important spheres of urban development, such as land-use planning and zoning, residential development, harmonization of urban landscape and so on.

Other Russian cities also have their own specific mechanisms of strategy implementation. For example, the City of Kazan used flagship projects". In Samara, the principle of "live strategies" 5 was applied and so on.

Another question worth considering is how applicable the specific strategy implementation mechanisms are in relation to other territories. Let us look, for example, at the implementation mechanisms defined by the Strategy of Ekaterinburg.

As it was said above, in Ekaterinburg, the capital of Sverdlovsk region, different groups of stake-

\footnotetext{
${ }^{4}$ For more on the Strategy of Socio-Economic Development of Municipal District Kazan until 2030, see: Resolution of Kazan City Duma of 14.12.2016 No. 2-12. Retrieved from: https://www.kzn.ru/o-kazani/strategiya-kazani-2030/

${ }^{5}$ For more on the Strategy of Comprehensive Development of the City District of Samara until 2025, see: Resolution of Samara City District Duma of 26.09.2013 No. 358. Retrieved from: http://samgd.ru/upload/mirrors/www.gordumasamara. ru/docs/decisions/1380139200/Strategiya ot 26.09.13.pdf
}

holders were involved in the process of strategic planning and implementation.

Sverdlovsk region has a unique advanced experience of designing and updating strategies of socio-economic development. Under the auspices of the Plenipotentiary Representative of the Ural Federal District and the Government of Sverdlovsk Region, the Unified Methodological Board of Strategic Planning and Development was established. The Board created general approaches to designing strategic planning documents on all levels by coordinating federal, regional and municipal strategic planning systems ${ }^{6}$. The resulting unified methodological guidelines and strategy requirements were then officially approved ${ }^{7}$. The main methodological principles proposed by the Board are as follows:

1. Top officials should be personally involved into strategic planning and strategy implementation. In other words, strategic planning should fall within the sphere of responsibility of top officials of regional executive government bodies and heads of municipalities. This function cannot be delegated to lower levels of the hierarchy. The frontline government officials should lead the process of strategic planning and implementation. This process should be well-structured, formalized and automated.

2. The strategy should be designed by those who are in charge of their home regions or cities and who are, therefore, interested in the prosperity of this territory although they may decide to employ external consultants.

3. Strategy is a "public agreement document", that is, a strategy should have a scientifically justified framework and it should balance the interests of the public, business and government, ensuring comprehensive and sustainable development of the territory. Therefore, it is crucial to engage all community groups into meaningful dialogue.

4. The efficiency of local government bodies is crucial for achieving the desired goals set by the strategy.

5. It is important to establish an institution of project managers. Specific leadership respon-

${ }^{6}$ Minutes of the Meeting of the Deputy of the Plenipotentiary Representative of the President of the Russian Federation in the Ural Federal District and the Working Group on Strategic Planning and Regional Development in the Ural Federal District of 01.07.2016 No. 12.

Minutes of the Meeting of the Unified Methodological Board of Strategic Planning and Development in the Ural Federal District under the Deputy of the Plenipotentiary Representative of the President of the Russian Federation in the Ural Federal District A. P. Moiseev of 14.11.2016 No. 22. 
sibilities need to be assigned for every project or program: responsible parties are designated in the corresponding government bodies.

6. It is necessary to ensure consistency, coordination and continuity of strategic and ongoing planning. Steps and indicators described in strategic documents should be systematically reflected in planning and control; the choice of specific measurable values, deadlines and stages should be justified. Therefore, it is important to establish strategic control points, which will make the whole process more controllable, make analysis of the situation less time-consuming and ensure efficient decision-making.

In Sverdlovsk region, each municipality had their own working groups and think tanks ("Government", "Business", "Academia", "Public", and "Media") and municipal education councils. The Council of Strategic Development of Sverdlovsk Region, a public collegial body, was established to create a system of strategic planning based on a single methodological framework, to examine and select draft strategic planning documents.

The second mechanism of implementation used in Ekaterinburg was the combination of project management with program management.

Project management became a widely discussed topic in Russia since the middle of 2016, when the Presidential Council for Strategic Development and Priority Projects was established (hereinafter referred to as the Council). The Council determined priority areas of national development and also set the aim of promoting project management principles and practices on the national level. Within a few months, the Government of the Russian Federation adopted the Decree No. 1050 of 15.10.2016 "On Organization of Project Activity in the Government of the Russian Federation" and thus put into force the Council's recommendations. By 2017, almost all federal ministries and regional governments had their own project management offices.

In 2018, project management principles started to be applied on the regional level. The regions which proved to be most active in this respect were Belgorod, Leningrad, Arkhangelsk, Primorye regions and Yamalo-Nenetsk and Khanty-Mansiisk autonomous districts. In 2018-2019, this trend spread to the majority of Russian regions. Some of them attempted ensure the compliance of their strategies with regional and federal projects. In some regions, local municipalities put forward their own project initiatives, and, as a result, some municipal projects were selected to be realized within the updated strategies of socio-economic development.

It should be noted that most of the projects, regardless of their officially declared level, are actually realized on the level of municipalities, which is why in many regions efforts are made to provide methodological support and consultancy for municipal authorities. From the methodological and practical point of view, it is particularly interesting to look at the experience of the following Russian regions.

In Perm region, it was decided to create a platform "Municipal Club" to discuss problems, needs and concerns of local communities and municipal authorities. All those interested in the improvement of life in municipalities and enhancement of the efficiency of municipal government could join the club.

As a part of the project "Municipal Home" in Krasnoyarsk region, the leading Russian and international experts conducted seminars on legal aspects of self-government for heads of municipalities, municipal civil servants and candidates for posts in municipal service.

Nizhny Novgorod region realized a number of social projects such as the project "Council of Young Deputies of Nizhny Novgorod region" aimed at enhancing cooperation among young deputies in representative bodies of municipalities and building a talent pool for municipalities. The purpose of the second project "The City to Live in" was to support grassroots initiatives in the sphere of environmental protection, urban beautification and creation of outdoor amenities in streets, neighbourhoods and residential districts. The third project "Social Development - Revival of Traditions" was aimed at encouraging young adults to participate in social development of their local areas and to preserve the cultural heritage of these areas through specialized social projects.

Samara region realized the project "Implementation of New Educational Mechanisms for Career Lift" aimed at organizing short-term training courses (business games) as a platform for exchange of experience and networking among young professionals.

In Bryansk region, project "Mutual Assistance" helps teenagers and young adults to cope with difficult life circumstances.

Sverdlovsk region also actively uses mechanisms of project management. The new management technologies were introduced to the region 
by the Decree of the Governor of Sverdlovsk Region of 14.02.2017 No. 84-УГ "On Organization of Project Activity in the Government of Sverdlovsk Region and Executive Government Bodies of Sverdlovsk Region”. Moreover, strategic projects are the key mechanisms of implementation of the Strategy for 2016-2030 ${ }^{8}$.

The innovative trend in socio-economic development of municipalities as basic spatial units focuses on the local community as the driving force behind project management. At the same time, practice shows that it is necessary to encourage local communities to participate in this process. Municipal strategies also need to be adjusted. One of the ways to involve local communities in strategic planning and management is to introduce a system of proactive budgeting.

Table 2 outlines the main characteristics of proactive budgeting.

\section{Proactive budgeting characteristics}

Table 2

\begin{tabular}{|c|c|c|}
\hline Characteristic & Content & Explanation \\
\hline \multirow[t]{4}{*}{$\begin{array}{l}\text { Financial and } \\
\text { budget-relat- } \\
\text { ed aspects }\end{array}$} & $\begin{array}{l}\text { Proactive budgeting } \\
\text { is a way of redistrib- } \\
\text { uting from } 1 \text { to } 10 \% \\
\text { of the municipal ex- } \\
\text { penditure budget by } \\
\text { a special committee }\end{array}$ & $\begin{array}{l}\text { The committee } \\
\text { consists of represen- } \\
\text { tatives of the local } \\
\text { community not in- } \\
\text { volved in municipal } \\
\text { government }\end{array}$ \\
\hline & $\begin{array}{l}\text { This mechanism be- } \\
\text { comes a part of the } \\
\text { budgeting process }\end{array}$ & $\begin{array}{l}\text { State and municipal } \\
\text { budgeting }\end{array}$ \\
\hline & $\begin{array}{l}\text { Principle of project } \\
\text { co-funding }\end{array}$ & $\begin{array}{l}\text { Attracting additional } \\
\text { funding sources }\end{array}$ \\
\hline & $\begin{array}{l}\text { Enhancing efficient } \\
\text { public spending }\end{array}$ & $\begin{array}{l}\text { Compliance with } \\
\text { municipal targeted } \\
\text { programs }\end{array}$ \\
\hline \multirow[t]{2}{*}{$\begin{array}{l}\text { Organization- } \\
\text { al aspect }\end{array}$} & $\begin{array}{l}\text { Includes various im- } \\
\text { plementation forms } \\
\text { and practices }\end{array}$ & $\begin{array}{l}\text { Crowdsourcing, } \\
\text { crowdfunding }\end{array}$ \\
\hline & $\begin{array}{l}\text { Involves members } \\
\text { of local community } \\
\text { into project activities }\end{array}$ & $\begin{array}{l}\text { Brainstorming new } \\
\text { ideas; designing, } \\
\text { realization and } \\
\text { control of specific } \\
\text { projects; evaluation } \\
\text { and selection of such } \\
\text { projects }\end{array}$ \\
\hline \multirow[t]{2}{*}{$\begin{array}{l}\text { Behavioural } \\
\text { aspect }\end{array}$} & \multicolumn{2}{|c|}{$\begin{array}{l}\text { Encourages careful and conscientious } \\
\text { treatment of the facilities built as a part of } \\
\text { the project }\end{array}$} \\
\hline & \multicolumn{2}{|c|}{$\begin{array}{l}\text { Changes the local community's attitude } \\
\text { towards budgeting }\end{array}$} \\
\hline \multirow{2}{*}{$\begin{array}{l}\text { Informational } \\
\text { aspect }\end{array}$} & \multicolumn{2}{|c|}{ Activates public indicators of development } \\
\hline & \multicolumn{2}{|c|}{$\begin{array}{l}\text { Makes public financial management trans- } \\
\text { parent by ensuring easy access to relevant } \\
\text { information }\end{array}$} \\
\hline
\end{tabular}

${ }^{8}$ For more on the Strategy of Socio-Economic Development of Sverdlovsk Region in 2016-2030, see: Law of Sverdlovsk Region of 21.12.2015 No. 151-O3. Retrieved from: http://strategy2030.midural.ru/sites/default/files/files/zakon no 151-oz.pdf
Our analysis of the data from the Proactive Budgeting Centre of the Financial Research Institute of the Ministry of Finance of the Russian Federation shows that many regions of Russia resort to proactive budgeting methods.

The third implementation mechanism was efficient coordination of strategic and territorial planning and management efforts.

This process is crucial for the strategy's viability. If strategic priorities do not take into account the specific needs and characteristics of this or that territory, they will remain nothing but a piece of highly unrealistic wishful thinking. The methodological guidelines for development (and updating) of municipal strategies in Sverdlovsk region specify the following requirement for the section "Strategy of Spatial Development" in these documents":

1. The aim of spatial development of municipalities should be clearly formulated and aligned with the main aim of municipal socio-economic development.

2 . The same refers to the goals of spatial development of municipalities.

3. The key performance indicators should be quantifiable and show the attainment of the aim and the corresponding goals, including those identified for specific stages of strategy implementation.

4. Analysis of municipal development should, among other things, consider the transformations of the municipality, its success or failure to achieve the goals set by the previous documents of territorial planning and description of the main problems that need to be dealt with as well as the positive and negative trends that need to be taken into account.

5. There should be a description of the concept (priority scenario) of spatial development, which sets the main aim and priorities by taking into account the potential and resources of this municipality and its functional zones (they need to correlate with the implementation mechanisms of priority projects included into the strategy).

6. There should be strategic indicators which determine the main criteria and requirements and can be used to assess the results of spatial development in general and the outcomes for specific functional zones.

7. The list of graphic materials should be included into the strategy as appendices.

The section on implementation mechanisms in strategies will help harmonize the pri-

${ }^{9}$ For more on the methodological guidelines for devising strategies of socio-economic development of municipal districts in Sverdlovsk region, see: Decree of the Government of Sverdlovsk region of 30.03.2017 No. 208-ПП. 
orities of socio-economic and territorial development of a certain municipality with its key characteristics.

It is important to conduct further research into the topic of strategic territorial development [24].

\section{Conclusion}

Strategic planning and management are important instruments which enable governments to cooperate with other stakeholder groups to achieve the desired goals. Our research findings are as follows:

Strategic planning in Russia went through several stages of development. Our analysis focused on the current trends by looking at strategic planning documents (strategies, strategic plans and so on) and found that such documents were initially designed in the absence of the corresponding legislation. The first to draw strategies of socio-economic development were large Russian cities. Even today, however, not all Russian regions have their own officially approved updated strategies, which makes it a relevant task to promote strategic planning and management and provide adequate methodological support.

We discussed the strategy implementation mechanisms used in Ekaterinburg and other million-plus Russian cities as well as the applicability of this experience in other Russian regions.

Since there are no generally accepted strategy implementation mechanisms, we have formulated a number of recommendations.
First, the section "Mechanisms of Strategy Implementation" should become an integral part of any strategy of socio-economic development since it describes the key principles of strategic management, monitoring and strategy updating.

Second, this section should define the stages, mechanisms and principles of strategy implementation and monitoring as well as the parties responsible for each stage. This section might include a description of new institutions necessary for strategy implementation, their powers, functions, sources of funding, performance indicators and forms of supervision and control.

Finally, it is recommended that this section should include a scheme of organization of strategic management, identifying the specific strategic areas and priorities of spatial development as well as the corresponding government bodies.

Mechanisms of strategy implementation are among the key elements of strategic management, in fact, these mechanisms are what makes a strategy viable. Introduction of universal methodological approaches, including those dealing with implementation mechanisms on all levels (from municipalities to macro-regions and the whole country), will provide a foundation for an efficient integral system of strategic planning and management.

One of the urgent tasks that needs to be addressed by the Russian government is to establish general methodological approaches to strategic planning and management of territories of different levels.

\section{References}

1. Vetrov, G. Y. (2009). Management of Municipal Economic Development. Moscow: Institut ekonomiki goroda. (In Russ.)

2. Risin, I. E., \& Shatalova, E. A. (2008). Innovation in the System of Strategic Planning of Urban Socio-Economic Development: International Experience. Innovatsionnyi vestnik region, (1), 4-7. (In Russ.)

3. Kleiner, G. B. (2010). Systemic Structure of Economy and Economic Policy. In: G. B. Kleiner (ed). Conference proceedings: Systems Analysis in Economics. Moscow, 24-25 November 2010. (pp. 24-25). Moscow: CEMl RAS. (In Russ.)

4. Porter, M. (2005). On Competition: Transl. from English. Moscow: Williams. (In Russ.)

5. Thompson, Jr., \& Strickland, III A. J. (2002). Strategic Management: Concepts and Cases, $12^{\text {th }}$ edition: Transl. from English. Moscow: Williams. (In Russ.)

6. Ansoff, I. (1999). The New Corporate Strategy. St. Petersburg: Piter. (In Russ.)

7. Ansoff, I. H. (ed.) (2007). Strategic Management: Classic Edition. St. Petersburg: Piter. (In Russ.)

8. Mintzberg, H., Quinn, J. B., \& Ghoshal, S. (2007). The Strategy Process. St. Petersburg: Piter. (In Russ.)

9. Animitsa, E. G., \& Vlasova, N. Y. (2010). Urban Studies. $4^{\text {th }}$ ed. Ekaterinburg: Ural State Economic University. (In Russ.)

10. Shishkina, E. A. (2013). Regional Strategic Planning: Development of Methodology and Instruments (Summary of a Dissertation for the Degree of Cand. Sc. in Economics). Ekaterinburg. (In Russ.) 
11. Zhikharevich, B. S. (2006). A Decade of Urban Development Strategies in Russia. Rossiyskoe ekspertnoe obozrenie, (2), 15. (In Russ.)

12. Silin, Y. P., Dvoryadkina, E. B., \& Antipin, I. A. (2018). The priorities of the strategic development of a new industrial city. Upravlenets = The Manager, 9(6), 2-16. (In Russ.) DOI: 10.29141/22185003-2018-9-6-1

13. Lavrikova, Y. G., Antipin, I. A., Pryadein, A. A., \& Suvorova, A. V. (2016). Major city development forecast: designing the innovative future. Economic and Social Changes: Facts, Trends, Forecast, 6(48), 214-235. DOI: 10.15838/esc.2016.6.48.12

14. Hagerstrand, T. (1967). Innovation Diffusion as a Spatial Process. Chicago: Univ.

15. Kelly, K. (1999). New rules for the new economy: 10 radical strategies for a connected world. Penguin.

16. Peshina, E. V., Animitsa, E. G., Bochko, V. S., \& Animitsa, P. E. (2010). Conceptual Approaches to Strategic Development of Mono-Towns. Ekaterinburg: Ural State University of Economics. (In Russ.)

17. Surnina, N. M., \& Shishkina, E. A. (2013). Developing Regional Strategic Planning Methodology: Enhancing Coordination and Efficiency. Upravlenets = The Manager, (1), 56-63. (In Russ.)

18. Antipin, I. A. (2011). Improvement of the Local Land Market of a Large City: Strategic and Territorial Planning (Methodological Framework). Munitsipalitet: ekonomika i upravlenie, (1), 050-061. (In Russ.)

19. Khan, M., Babar, M., Ahmed, S. H., Shah, S. C., \& Han, K. (2017). Smart city designing and planning based on big data analytics. Sustainable Cities and Society, 35, 271-279.

20. Kim, T. H., Ramos, C., \& Mohammed, S. (2017). Smart city and IoT. Future Generation Computer Systems, 76, 159-162.

21. Mora L., Bolici R., Deakin M. (2017) The first two decades of smart-city research: A bibliometric analysis. Journal of Urban Technology, 24(1), 3-27. DOI: $10.1080 / 10630732.2017 .1285123$

22. Morrar, R., Arman, H., \& Mousa, S. (2017). The Fourth Industrial Revolution (Industry 4.0): A Social Innovation Perspective. Technology Innovation Management Review, 7(11), 12-20. DOI: 10.22215/timreview/1117

23. Ojasalo, J., \& Kauppinen, H. (2016). Collaborative innovation with external actors: an empirical study on open innovation platforms in smart cities. Technology Innovation Management Review, 6(12). DOI: $\underline{10.22215 / \text { timreview/1041 }}$

24. Antipin, I. A., \& Kazakova, N. V. (2016). The conceptual base of the spatial development strategy of a municipal unit. Rossiiskoe predprinimatelstvo $=$ Russian Journal of Entrepreneurship, 17(8), 1011-1026. DOI: 10.18334/rp.17.8.35119

\section{Information about the author}

Ivan A. Antipin - PhD in Economics, associate professor of the Department of Regional, Municipal Economy and Management, Ural State Economic University (62/45 Str. 8 Marta/Narodnoy voli, 620144, Ekaterinburg, Russia); e-mail: aia87@mail.ru

ARTICLE INFO: received May 16, 2019; accepted August 06, 2019

\section{Информация об авторе}

Антипин Иван Александрович - кандидат экономических наук, доцент кафедры региональной, муниципальной экономики и управления, Уральский государственный экономический университет (620144, Россия, Екатеринбург, ул. 8 марта/Народной воли, 62/45); email: aia87@mail.ru

ИНФОРМАЦИЯ О СТАТЬЕ: дата поступления 16 мая 2019 г.; дата принятия к печати 6 августа 2019 г.

This work is licensed under a Creative Commons Attribution 4.0 International License

Эта работа лицензируется в соответствии с Creative Commons Attribution 4.0 International License 